\title{
NUTRITIONAL COMPOSITION OF PLANT-BASED TEXTURE: MODIFIED FOODS FOR DYSPHAGIA PATIENTS
}

\author{
Solvita Kampuse ${ }^{1, \#}$, Liene Ozola ${ }^{1}$, Zanda Krūma ${ }^{1}$, Dace Kḷava ${ }^{1}$, Ruta Galoburda ${ }^{1}$, \\ Evita Straumite $^{1}$, and Inese Siksna ${ }^{2}$ \\ ${ }^{1}$ Faculty of Food Technology, Latvia University of Life Sciences and Technologies, 22 Rīgas Str., Jelgava, LV-3004, LATVIA \\ 2 Institute of Food Safety, Animal Health and Environment "BIOR", 3 Lejupes Str., Rīga, LV-1076, LATVIA \\ \# Corresponding author, Solvita.Kampuse@ @llu.Iv
}

Communicated by Sandra Muižniece-Brasava

\begin{abstract}
There are approximately 590 million people in the world with swallowing disorders (dysphagia), who need texture-modified foods to ensure nutritional intake on a daily basis. The aim of this research was to create new texture-modified products and to evaluate their bioactive and mineral compound concentration. Nine new products (five desserts and four puree-soups) were developed from plant-based ingredients with addition of a source of protein, canola oil, ascorbic acid, and other ingredients. Obtained samples were vacuum-cooked, sterilised at $115^{\circ} \mathrm{C}$ for 5 min and tested for their bioactive compound concentration (total carotene and phenol concentration, and $A B T S$ and DPPH radical scavenging activity), and concentration of seven vitamins and thirteen minerals important in human nutrition. The obtained data showed that bioactive compound concentration varied from sample to sample, which was expected due to the varied ingredients of each product. Mineral compound concentration analysis showed low levels of iodine, molybdenum, and selenium. The vitamin analysis showed traces of vitamin $D_{3}$ and low levels of $B$ group vitamins. Overall, the analysed product composition indicated that the natural background of these products is insufficient for ensuring the human body with all of the necessary vitamins and minerals, and the best solution could be the supplementation of these products with complexes of vitamins and minerals.
\end{abstract}

Keywords: special medical purpose food, bioactive compounds, mineral compounds.

\section{INTRODUCTION}

It has been estimated that about 590 million people around the world suffer from the disorder dysphagia and need texture-modified foods to ensure proper nutritional intake on a daily basis (Cichero et al., 2017; Klava et al., 2019). The need for a texture-modified diet is most commonly by groups of people with a generally weakened organism, who need a 'soft diet', and those they have oro-pharyngeal dysphagia. Generally unwell people can usually satisfy their dietary needs by consuming 'soft food', however individuals who suffer from oro-pharyngeal dysphagia may be at risk of choking and/or aspiration of food into their lungs (National Patient Safety Agency, 2011). Dysphagia is a condition that impairs a person's ability to swallow or chew. It is estimated that approximately $15 \%$ of community dwelling, old adults are affected by this condition. This is also very common among patients and nursing home resi- dents (Okkels et al., 2018). People who suffer from dysphagia often have a variety of other medical conditions that cause this disorder. It is also a significant factor among the causes of undernutrition for elderly and has been associated with increased mortality (Sungsinchai et al., 2019; Okkels et al., 2018).

Not only the textural characteristics, but also the nutritional content of these products have a very important role. Sungsinchai et al. (2019) reported that the European Society of Parenteral and Enteral Nutrition (ESPEN) and American Society for Parenteral and Enteral Nutrition (ASPEN) recommend that ambulant and bedridden patients with cancer should have daily energy intakes of 30 to 35 and 20 to 25 kcal per kg body weight, respectively, and a minimum of $1 \mathrm{~g} \cdot \mathrm{kg}^{-1}$ body weight of daily protein. Costa et al. (2019) and Sungsinchai et al. (2019) have suggested an energy requirement of $25 \mathrm{kcal}$ per $\mathrm{kg}$ a day for elderly persons with 
dysphagia at relatively normal nutritional status, but $35 \mathrm{kcal}$ per $\mathrm{kg}$ a day for malnourished elderly with dysphagia.

The European Union has provided regulations regarding the specific compositional and information requirements for food for special medical purposes.

Thickened fluids are classified into several levels or classes, depending on their consistency (Moret-Tatay et al., 2015). The terminology used to describe these levels varies among countries (Cichero et al., 2017; Beck et al., 2018), but at least three of the levels have been commonly agreed upon: nectar-syrup (mildly thick), custard-honey (moderate thick), and spoon-pudding (extremely thick). Consistencies are classified depending on the values of viscosity measured at $50 \mathrm{~s}^{-1}$, which is the shear rate considered to be representative of the swallowing process; although in reality a large range of shear rates (from 1 to $1000 \mathrm{~s}^{-1}$ ) are involved in the whole oral process of the bolus (National Dysphagia Diet Task Force, 2002; Zargaraan et al., 2013; Moret-Tatay et al., 2015).

The most common approach for solving the nutritional needs of dysphagia patients is the consumption of artificially combined mixtures of vitamins, mineral compounds, carbohydrates, proteins and some oils with added flavours (like vanilla, banana, strawberry) offered by big companies. These flavours are very common and for long-time users could become tedious to consume. However, developing more natural and regular tasting options could improve their appetite and help them to feel more included in the regular society.

The aim of this study was to create new texture-modified products and to evaluate their bioactive compound, vitamin and mineral compound concentration.

\section{MATERIALS AND METHODS}

Nine new products (five desserts and four puree-soups) were developed from plant-based ingredients mostly grown in Latvia, with added sources of protein, canola oil, ascorbic acid, and other ingredients. Composition of five dessert and four puree-soup recipes from fruit and vegetable purees and juices are presented in Table 1 .

In total, 1500-g samples of each product were prepared and vacuum-cooked and then filled in five glass jars of $250 \mathrm{~g}$ each. The samples were then sterilised at $115^{\circ} \mathrm{C}$ for $5 \mathrm{~min}-$ utes. The technological steps are presented in Figure 1. Chemical analysis of three of these jars was conducted in the Faculty of Food Technology, Latvia University of Life Sciences and Technologies, and the other two in the Institute of Food Safety, Animal Health and Environment "BIOR". The samples were tested for their bioactive com-

Table 1. The recipes of fruit and vegetable desserts for dysphagia patients

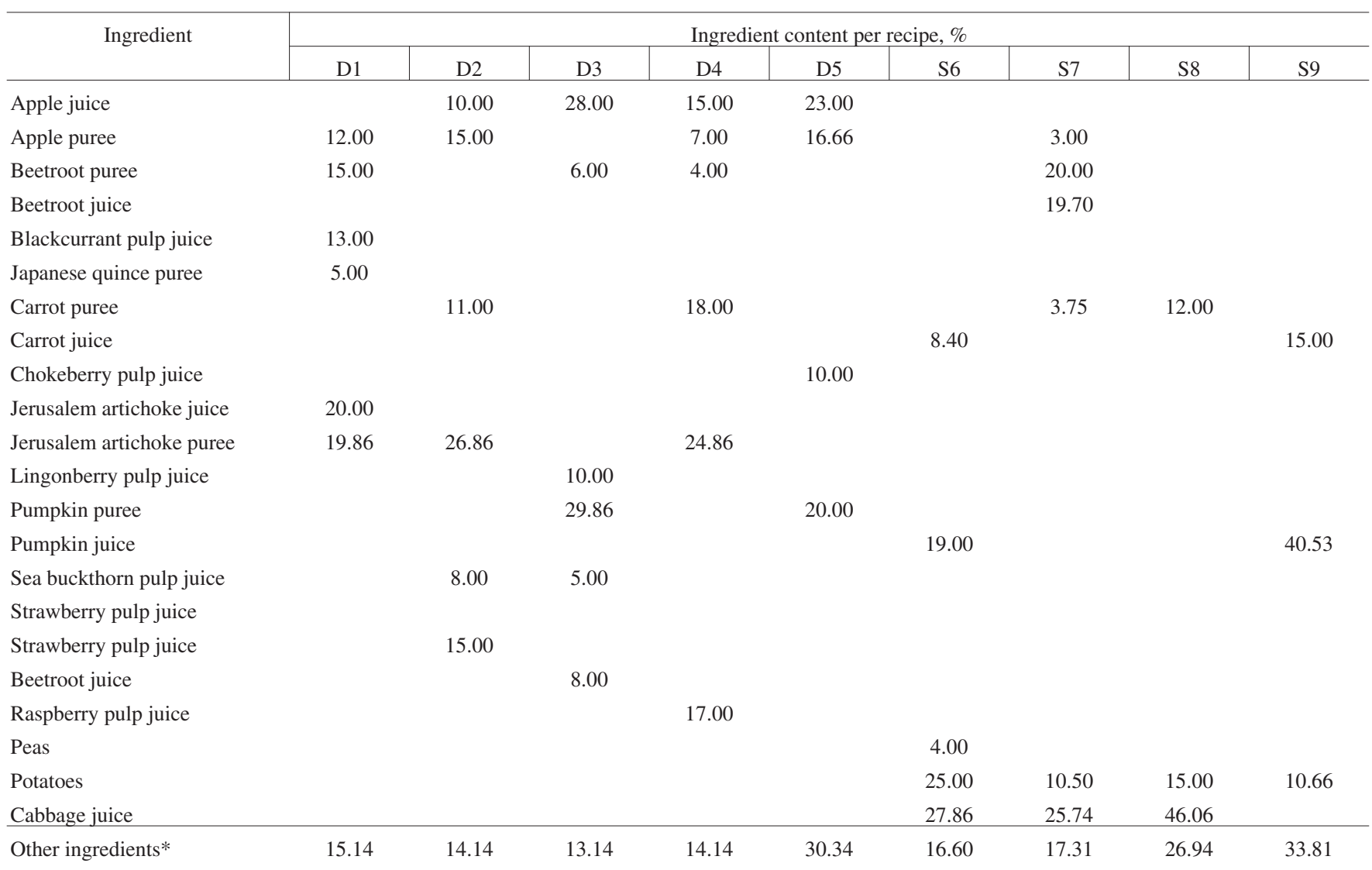

\footnotetext{
* Other added ingredients were as follows: for desserts: whey protein isolate (4.00\%), refined rapeseed oil (6.00\%), sugar); L-arginine, ascorbic acid, and sweet cream and cinnamon for D5. For puree-soups: whey protein isolate (7.00\%), hemp protein (1.00 \%), refined canola oil (5-6 \%), L-arginine, salt; ascorbic acid, spices and herbs, cream for S8, and cheese spread for S9.
} 


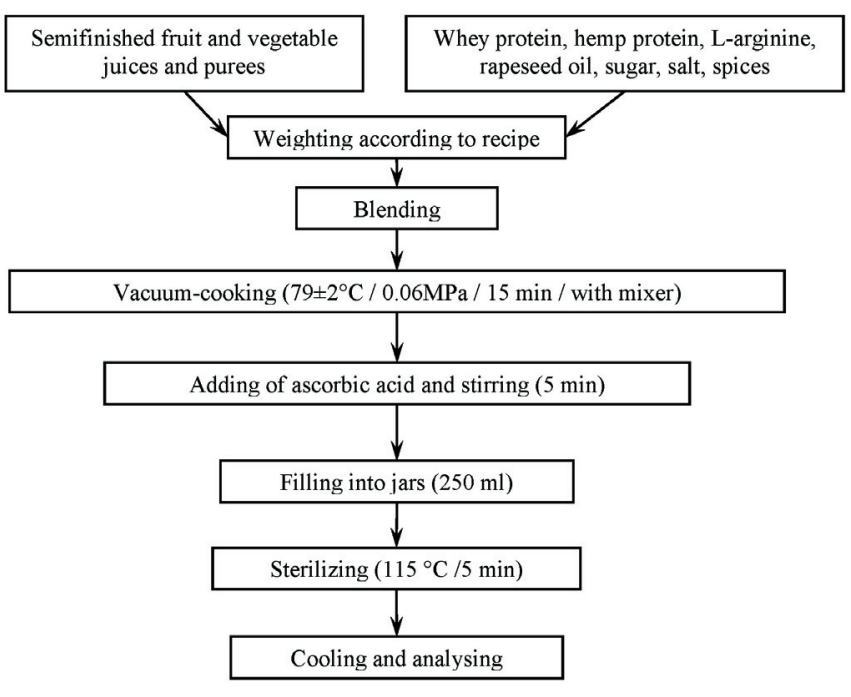

Fig. 1. Production technology of products for dysphagia patients.

pound concentration (total carotene and phenol concentration, and ABTS and DPPH antiradical activity) using a spectrophotometer JENWAY 6705 UV (Bibby Scientific Ltd., UK), and vitamin concentration $\left(\mathrm{A}, \mathrm{B}_{1}, \mathrm{~B}_{2}, \mathrm{~B}_{6}, \mathrm{~B}_{9}\right.$, $\mathrm{D}_{3}$, and $\mathrm{E}$ ) and mineral compound concentration ( $\mathrm{Zn}, \mathrm{Fe}$, $\mathrm{Cr}, \mathrm{I}, \mathrm{Ca}, \mathrm{K}, \mathrm{Mg}, \mathrm{Mn}, \mathrm{Mo}, \mathrm{Na}, \mathrm{Cu}, \mathrm{Se}$, and $\mathrm{Cd}$ ).

Vitamins A and D were analysed with LC-DAD (liquid chromatography), and other vitamins except folic acid with LC-FLD; folic acid concentration was determined with Nephelometry.

Mineral compound concentration was determined with inductively coupled plasma mass spectrometry (ICP-MS). The analyses of vitamins and mineral compounds were done according to the official methods of the Institute of Food Safety, Animal Health and Environment "BIOR".

The total concentration of carotenes was determined by spectrophotometry using a spectrophotometer JENWAY 6705 UV (Bibby Scientific Ltd., UK) at wavelength $440 \mathrm{~nm}$ according to published methods (Ermakov, 1987, pp. 112-113; Poludek-Fabini and Beirix, 1981) modified by Ozola and Kampuse (2018). The standard curve was made using $\mathrm{K}_{2} \mathrm{Cr}_{2} \mathrm{O}_{7}$ standard solution. The analyses were done in two independent replications with three repetitions each. To evaluate potential consumption of vitamin A, the concentration of total carotenes was calculated to Vitamin A using a conversion factor of 22:1 and estimated together with detected vitamin A (formula 1):

$\mathrm{Rc}=\mathrm{TC} / 22+\mathrm{R}$

where Rc - total calculated retinol concentration;

TC - total detected concentrationof carotenes in sample;

$\mathrm{R}$ - detected concentrationof retinol or vitamin A.

Total phenol concentration was determined using Folin Ciocalteus reagent according to Singleton et al. (1999) with some modifications (Ozola and Kampuse, 2018). The analy- ses were done in two independent replications with three repetitions each.

Antiradical activity from the same extracts prepared for detection of total phenol concentration was measured on the basis of scavenging activity of the stable 2,2-diphenyl-1picrylhydrazyl (DPPH') radical as outlined by $\mathrm{Yu}$ et al. (2003). The absorbance was measured at $517 \mathrm{~nm}$. Antiradical activity was also estimated by 2,2-azino-bis(3ethylbenz-thiazoline-6-sulfonic) acid $\left(\mathrm{ABTS}^{-+}\right)$radical cation assay (Floegel et al., 2011). The absorbance was measured at $734 \mathrm{~nm}$. Antioxidant activity was expressed as $\mathrm{mg}$ TE $100 \mathrm{~g}^{-1}$ fresh weight. Analyses were done in two independent replications with three repetitions each.

Experimental results were analysed using Microsoft Excel 2016. Single factor analysis of variance (ANOVA) was used to determine differences among samples. Correlation coefficients were calculated between total phenol concentration and antiradical activity. Differences were considered as significant at $p<0.05$.

\section{RESULTS}

Commission delegated regulation (EU) 2016/128 specifies the values of vitamins and mineral compounds in food for a special medical purpose for two types of people groups, to satisfy their nutritional requirements: a) for infants and b) other than that developed to satisfy the nutritional requirements of infants. For the purpose of this study, the requirement for other than satisfying the nutritional requirements of infants was taken as a base line in comparing the obtained data to some of the regulatory compounds. The values of these compounds are calculated per energy intake (100 kJ or $100 \mathrm{kcal})$.

The obtained data showed that bioactive compound concentration varied from sample to sample, which was expected due to the varied ingredient list of each product.

There were significant differences $(p<0.05)$ in total carotene concentration among tested puree-soup and dessert samples. All puree-soups were a good source of total carotenes, and sample S7 had the highest concentration $(2.98 \pm$ $0.43 \mathrm{mg} \cdot 100 \mathrm{~g}^{-1}$ or $2.63 \mathrm{mg} \cdot 100 \mathrm{kcal}^{-1}$ ), where the main ingredients were beet roots and carrots (Fig. 2).

Desserts had a lower total carotene concentration than puree-soups, and only D3 (with $1.5 \pm 0.02 \mathrm{mg} \cdot 100 \mathrm{~g}^{-1}$ or $1.32 \mathrm{mg} \cdot 100 \mathrm{kcal}^{-1}$ ) had a similar total carotene concentration as the majority of the soup recipes (Fig. 2). This sample contained pumpkin puree and sea buckthorn pulp juice, which are good sources of carotenes. D5 contained very low concentration of total carotenes but this was the only dessert sample that contained also vitamin A (Table 2).

All samples significantly $(p<0.05)$ differed also in total phenol concentration. In contrast to total carotene concentration the highest total phenol concentration was in dessert samples. The highest total phenol concentration calculated 


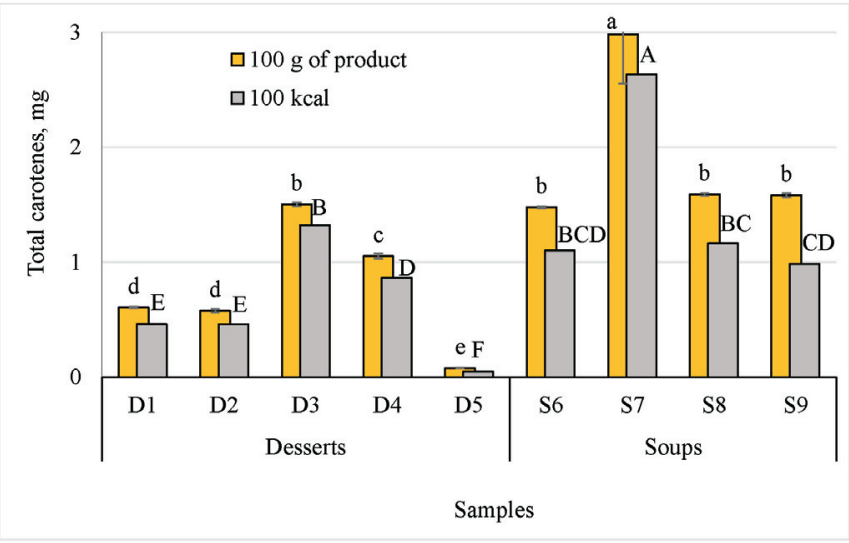

Fig. 2. Total carotene concentration in products for dysphagia patients. The same letter means that there are no significant differences between corresponding values $(p>0.05)$.

per $100 \mathrm{~g}$ of product was detected in D5 (107.22 \pm 0.71 $\mathrm{mg} \cdot 100 \mathrm{~g}^{-1}$ ) (Fig. 3), which was made with apple juice and puree, chokeberry puree, pumpkin puree, and cinnamon. However, the highest total phenol concentration calculated per $100 \mathrm{kcal}$ was for D3 $\left(79.99 \pm 1.09 \mathrm{mg} \cdot 100 \mathrm{kcal}^{-1}\right)$, which was composed of apple juice, lingonberry pulp, pumpkin, sea buckthorn, and beetroot. In both samples, the ingredients with extremely high total phenol content were lingonberry and chokeberry, as reported also by other literature sources (Drózdz et al., 2018; Olas, 2018).

Very similar tendencies as total phenol concentration were shown by DPPH antiradical activity. The samples significantly $(p<0.05)$ differed in DPPH antiradical activity and the highest antiradical activity calculated per $100 \mathrm{~g}$ of product was detected in D5 (91.92 $\pm 0.37 \mathrm{mg} \cdot 100 \mathrm{~g}^{-1}$ ) (Fig. 4), and the highest DPPH activity calculated per $100 \mathrm{kcal}$ was in D2 $\left(69.49 \pm 3.41 \mathrm{mg} \cdot 100 \mathrm{kcal}^{-1}\right)$, which was composed of apple, carrot, Jerusalem artichoke, sea buckthorn, and

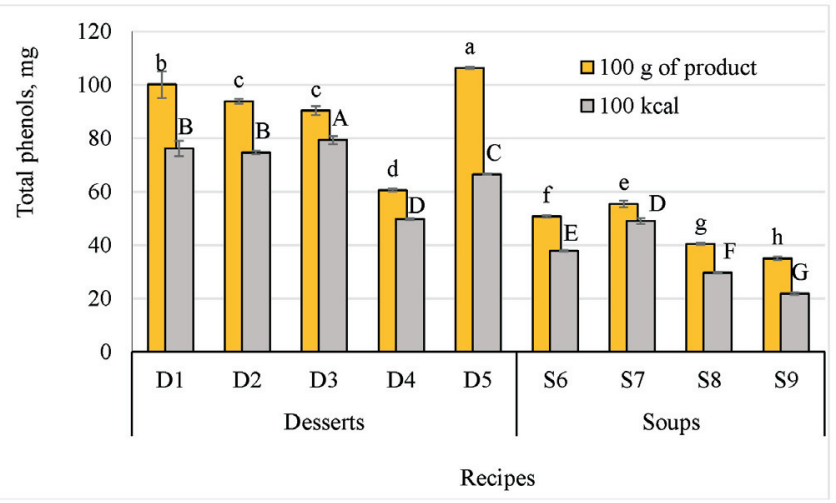

Fig. 3. Total phenol concentration in products for dysphagia patients. The same letter means that there are no significant differences between corresponding values $(p>0.05)$.

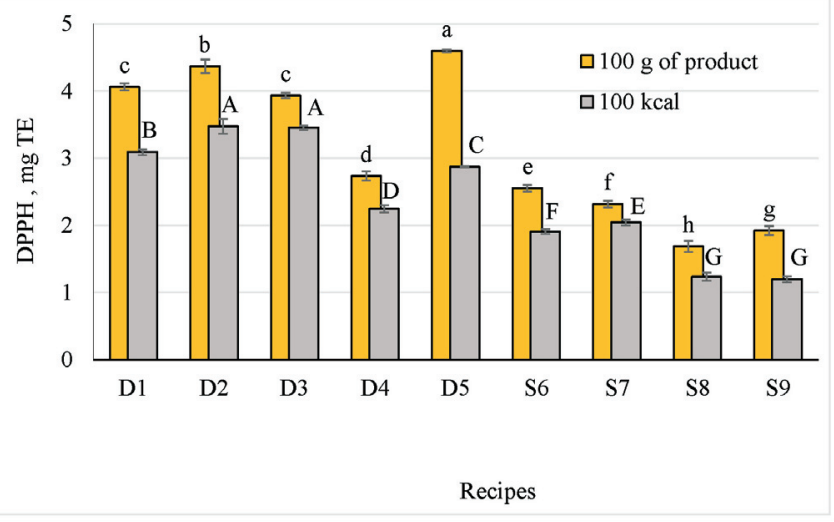

Fig. 4. DPPH antiradical activity of products for dysphagia patients. The same letter means that there are no significant differences between corresponding values $(p>0.05)$.

strawberries as the main ingredients. The lowest DPPH activity per $100 \mathrm{kcal}$ occurred in puree-soup S9 $(23.92 \pm 1.31$ $\left.\mathrm{mg} \cdot 100 \mathrm{kcal}^{-1}\right)$.

Table 2. The concentration of vitamins in products for dysphagia patients, mg per $100 \mathrm{kcal}$ of product

\begin{tabular}{|c|c|c|c|c|c|c|c|c|}
\hline \multirow{2}{*}{\multicolumn{2}{|c|}{ Sample }} & \multicolumn{7}{|c|}{ Vitamins } \\
\hline & & A & $\mathrm{B} 1$ & $\mathrm{~B} 2$ & B3 & B6 & B9 & $\mathrm{E}$ \\
\hline \multicolumn{2}{|c|}{ Recommended (min)* } & 0.035 & 0.060 & 0.080 & 10.000 & 0.080 & 0.010 & 0.500 \\
\hline \multicolumn{2}{|c|}{ Recommended $(\max )^{*}$} & 0.180 & 0.500 & 0.500 & 50.000 & 0.500 & 0.050 & 3.000 \\
\hline \multirow[t]{5}{*}{ Desserts } & D1 & $<*$ & $<$ & $<$ & $0.286 \downarrow$ & $0.030 \downarrow$ & $0.022 \uparrow$ & $3.620 \uparrow \uparrow$ \\
\hline & $\mathrm{D} 2$ & $<$ & $<$ & $<$ & $<$ & $0.032 \downarrow$ & $0.028 \uparrow$ & $3.874 \uparrow \uparrow$ \\
\hline & D3 & $<$ & $<$ & $<$ & $0.171 \downarrow$ & $0.049 \downarrow$ & $0.021 \uparrow$ & $4.101 \uparrow \uparrow$ \\
\hline & D4 & $<$ & $<$ & $<$ & $0.333 \downarrow$ & $0.039 \downarrow$ & $0.024 \uparrow$ & $3.770 \uparrow \uparrow$ \\
\hline & D5 & $0.029 \downarrow$ & $<$ & $<$ & $0.177 \downarrow$ & $0.031 \downarrow$ & $0.016 \uparrow$ & $2.318 \uparrow$ \\
\hline \multirow[t]{4}{*}{ Puree-soups } & S6 & $<$ & $0.025 \downarrow$ & $0.021 \downarrow$ & $0.543 \downarrow$ & $0.080 \rightarrow$ & $0.037 \uparrow$ & $3.047 \uparrow$ \\
\hline & S7 & $<$ & $0.029 \downarrow$ & $0.023 \downarrow$ & $<$ & $0.065 \downarrow$ & $0.049 \uparrow$ & $3.745 \uparrow \uparrow$ \\
\hline & S8 & $0.023 \downarrow$ & $0.029 \downarrow$ & $0.044 \downarrow$ & $0.485 \downarrow$ & $0.097 \uparrow$ & $0.028 \uparrow$ & $2.570 \uparrow$ \\
\hline & S9 & $0.038 \uparrow$ & $0.014 \downarrow$ & $0.031 \downarrow$ & $0.424 \downarrow$ & $0.053 \downarrow$ & $0.030 \uparrow$ & $0.827 \uparrow$ \\
\hline **Detection le & $100 \mathrm{~g}-1)$ & 0.007 & 0.005 & 0.003 & 0.003 & 0.003 & 0.003 & 0.01 \\
\hline
\end{tabular}

* Commission delegated regulation (EU) 2016/128 specifies the values of vitamins and mineral compounds in food for special medical purpose for two types of people groups, to satisfy their nutritional requirements: other than that developed to satisfy the nutritional requirements of infants,

$\downarrow$ lower concentration of vitamins than min, $\rightarrow$ the same concentration as min, $\uparrow$ higher concentration of vitamins than min, $\uparrow \uparrow$ higher concentration than max, < below detection level 


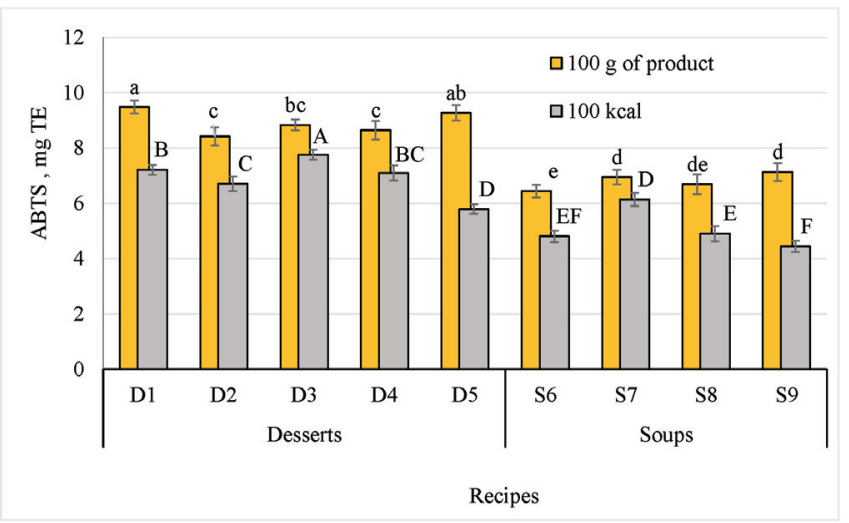

Fig. 5. $\mathrm{ABTS}^{+}$antiradical activity of products for dysphagia patients. The same letter means that there are no significant differences between corresponding values $(p>0.05)$.

Although there were significant differences between individual samples in $\mathrm{ABTS}^{+}$antiradical activity, in general all dessert recipe results were similar and also the puree-soup recipes had rather similar $\mathrm{ABTS}^{+}$activity (Fig. 5), compared to total phenol concentration and DPPH antiradical activity.

The highest antiradical activity calculated per $100 \mathrm{~g}$ of product was detected in D1 $\left(189.60 \pm 4.70 \mathrm{mg} \cdot 100 \mathrm{~g}^{-1}\right)$ (Fig. 4) with apple, beetroot, Jerusalem artichoke, and blackcurrants as the main ingredients, and the highest $\mathrm{ABTS}^{+}$activity calculated per $100 \mathrm{kcal}$ was for D3 (155.14 $\pm 3.97 \mathrm{mg} \cdot 100 \mathrm{kcal}^{-1}$ ).

Puree-soup and dessert samples also varied significantly in the concentration of mineral compounds. All puree-soup and dessert samples had an average or high amount of potassium (K) according to Commission Delegated regulation (EU) 2016/128 "Values for vitamins and minerals in food for special medical purposes other than that developed to satisfy the nutritional requirements of infants" recommendations. The highest potassium concentration (239.36 $\mathrm{mg} \cdot 100 \mathrm{kcal}^{-1}$ ) was detected in puree-soup S7 (Table 3). It was also possible to provide the necessary amounts of chromium and manganese with all samples, but the amount of magnesium was sufficient for all samples except dessert sample D5, in which the values for this element were slightly less than recommended in Commission delegated regulation (EU) 2016/128. The Mg concentration in S7 was even higher than the given maximal value recommended (Table 2). Mineral compounds such as calcium and sodium were in sufficient amounts in all puree-soup samples, but all desserts contained less than the given minimal recommended norms. The minimum required amount of copper could be provided only by two samples - D4 and S7. Similarly, only two samples could achieve the required amount of zinc: D4 and S8, and the required amount of iron - only in one puree-soup sample (S8).

The microelements iodine, molybdenum and selenium were below the detection limits in all formulations.

It is known that fruits and vegetables are not good sources of $\mathrm{B}$ group vitamins, which was also shown in this study. Vitamins $\mathrm{B}_{1}, \mathrm{~B}_{2}, \mathrm{~B}_{3}$, and $\mathrm{B}_{6}$ were less than given recommendations in the Commission delegated regulation (EU) $2016 / 128$, and the vitamins $B_{1}$ and $B_{2}$ were even below detection limits for all desserts. Unlike other B group vitamins, all analysed products provided sufficient concentration of Vitamin B9 for dysphagia patients. Vitamin A was ensured only with S9, while vitamin E was present in sufficient amounts in all of the studied samples, and in four desserts and one puree-soup samples it was even exceeded (Table 2). Vitamin $\mathrm{D}_{3}$ was below the limit of detection in all formulations, so it was not included in the results.

Table 3. Concentration of mineral compounds in products for dysphagia patients, per $100 \mathrm{kcal}$ of product

\begin{tabular}{|c|c|c|c|c|c|c|c|c|c|c|}
\hline \multirow{2}{*}{\multicolumn{2}{|c|}{ Sample }} & \multicolumn{9}{|c|}{ Mineral compounds } \\
\hline & & Znmg & $\mathrm{Fe}, \mathrm{mg}$ & $\mathrm{Cr}, \mathrm{mkg}$ & $\mathrm{Ca}, \mathrm{mg}$ & $\mathrm{K}, \mathrm{mg}$ & $\mathrm{Mg}, \mathrm{mg}$ & $\mathrm{Mn}, \mathrm{mg}$ & $\mathrm{Na}, \mathrm{mg}$ & $\mathrm{Cu}, \mathrm{mg}$ \\
\hline \multicolumn{2}{|c|}{ Recommended $(\min )^{*}$} & 0.500 & 0.500 & 1.250 & 35.000 & 80.000 & 7.500 & 0.050 & 30.000 & 0.060 \\
\hline \multicolumn{2}{|c|}{ Recommended $(\max )^{*}$} & 1.500 & 2.00 & 15.000 & 175.000 & 295.000 & 25.000 & 0.500 & 175.000 & 0.500 \\
\hline \multirow[t]{4}{*}{ Desserts } & D1 & $0.388 \downarrow$ & $0.225 \downarrow$ & $2.205 \uparrow$ & $28.367 \downarrow$ & $206.099 \uparrow$ & $11.408 \uparrow$ & $0.152 \uparrow$ & $8.366 \downarrow$ & $0.058 \downarrow$ \\
\hline & $\mathrm{D} 2$ & $0.309 \downarrow$ & $0.135 \downarrow$ & $3.739 \uparrow$ & $25.060 \downarrow$ & $172.633 \uparrow$ & $9.387 \uparrow$ & $0.159 \uparrow$ & $8.751 \downarrow$ & $0.055 \rightarrow$ \\
\hline & D4 & $0.830 \uparrow$ & $0.189 \downarrow$ & $4.681 \uparrow$ & $27.185 \downarrow$ & $173.292 \uparrow$ & $10.759 \uparrow$ & $0.164 \uparrow$ & $12.319 \downarrow$ & $0.078 \uparrow$ \\
\hline & D5 & $0.289 \downarrow$ & $0.062 \downarrow$ & $1.375 \uparrow$ & $23.743 \downarrow$ & $91.846 \uparrow$ & $7.248 \downarrow$ & $0.125 \uparrow$ & $6.248 \downarrow$ & $0.031 \downarrow$ \\
\hline \multirow[t]{3}{*}{ Puree-soups } & S6 & $0.373 \downarrow$ & $0.433 \downarrow$ & $1.568 \uparrow$ & $43.459 \uparrow$ & $182.945 \uparrow$ & $20.609 \uparrow$ & $0.194 \uparrow$ & $81.392 \uparrow$ & $0.049 \downarrow$ \\
\hline & S7 & $0.442 \downarrow$ & $0.442 \downarrow$ & $3.003 \uparrow$ & $51.316 \uparrow$ & $239.357 \uparrow$ & $26.497 \uparrow \uparrow$ & $0.297 \uparrow$ & $141.318 \uparrow$ & $0.099 \uparrow \uparrow$ \\
\hline & S8 & $0.820 \uparrow$ & $0.584 \downarrow$ & $2.270 \uparrow$ & $57.191 \uparrow$ & $168.424 \uparrow$ & $21.236 \uparrow$ & $0.220 \uparrow$ & $123.755 \uparrow$ & $0.058 \rightarrow$ \\
\hline \multicolumn{2}{|c|}{ Detection level $\left(\mathrm{mg} \cdot 100 \mathrm{~g}^{-1}\right)$} & 0.02 & 0.1 & 0.1 & 2.0 & 2.0 & 2.0 & 0.02 & 2.0 & 0.05 \\
\hline
\end{tabular}

* Commission delegated regulation (EU) 2016/128 specifies the values of vitamins and mineral compounds in food for special medical purpose for two types of people groups, to satisfy their nutritional requirements: other than that developed to satisfy the nutritional requirements of infants,

$\downarrow$ lower concentration of mineral compounds than min, $\rightarrow$ the same content as min, $\uparrow$ higher content of mineral compounds than min, $\uparrow \uparrow$ higher content than $\max$ 


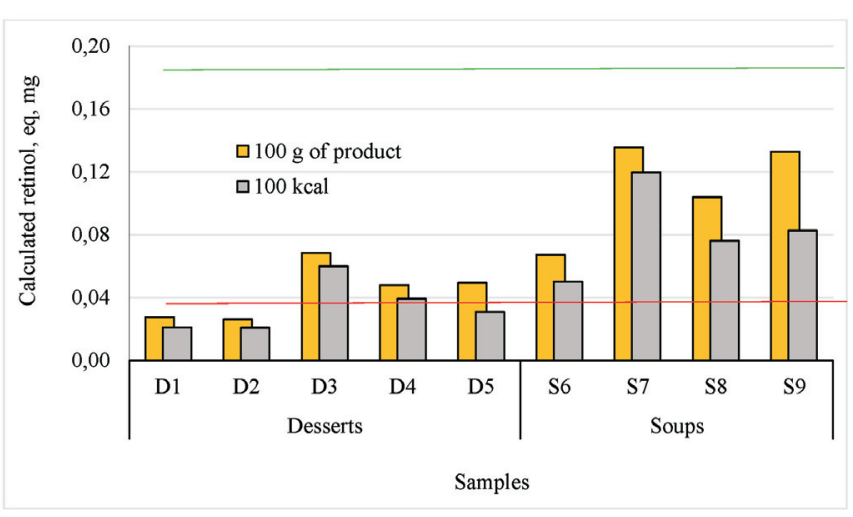

Fig. 6. Calculated retinol equivalent (vit. A) content in products for dysphagia

max recommended value for vitamin A (mg.100 kcal $\left.{ }^{-1}\right)$ based on Commission delegated regulation (EU) 2016/128;

min recommended value for vitamin A $\left(\mathrm{mg} \cdot 100 \mathrm{kcal}^{-1}\right)$ based on Commission delegated regulation (EU) 2016/128.

\section{DISCUSSION}

According to findings of Tang (2010), provitamin A carotenoids from various foods have been shown to have an almost 8-fold difference in $\beta$-carotene conversion factors (on a weight basis) that ranged from $3.6: 1$ to $28: 1$ with Golden Rice and leafy vegetables, respectively, and thus have different values in terms of vitamin A nutrition. The major factor that affects the vitamin A provitamin carotenoid value is the food matrix. Conversion factor for fruits and leafy vegetables have been reported as 12:1 and 28:1 (Khan et al., 2007), and for carrots - 15:1 (Tang et al., 2005). Taking into account this information and the specific fruits and vegetables and fruits used in our investigations, an average conversion factor of 22:1 was adopted in our study to evaluate potential consumption of vitamin A. The calculations showed that all puree-soup samples can ensure the necessary vitamin A amount to $100 \mathrm{kcal}$ of product according to recommendations of the regulation, but for the dessert samples D1, D2, and D5, the potential vitamin A content was lower than the recommended minimum (Fig. 6). As patient daily intake will consist of both product groups (pureesoups and desserts), it is possible to ensure the necessary daily intake of vitamin A without adding extra retinol additive.

Phenols have traditionally been considered as antinutritive compounds due to the adverse effect of one of their main components, tannins, on protein digestibility. However, actually there is an increased interest in these compounds, because they have been associated with the inhibition of atherosclerosis and cancer. The bioactivity of phenolics may be related to their antioxidant behaviour, which is attributed to their ability to chelate metals, inhibit lipoxygenase and scavenge free radicals (Martínez-Valverde et al., 2000). However, there is no clear evidence for the required intake of polyphenols in a human body and it could be influenced by many different factors. Del Rio et al. (2013) concluded that "A number of studies have been recently appearing in the literature overcoming previous limitations in the approaches used to unravel the putative mechanisms of action behind the protective effects of (poly)phenols. Identifying metabolites and catabolites and testing them in cell-based experimental models at physiological concentrations are the only ways to fully understand if the in vivo observations actually have molecular basis. It is apparent that they do not act simply as antioxidants in vivo, and their diverse effects are, in most instances, based on more complex and specific modes of action". Therefore, there are no strict limitations for polyphenol intake in the diet for patients. However, if we compare the obtained data with data of other plant-based products, the evaluated samples contained the average amount of phenolic compounds and could ensure the necessary intake of these phytochemicals. In a complex study encompassing European countries, the researchers found interesting data about the total phenol intake in Europe. Zamora-Ros et al. (2013) reported that the highest total polyphenol intake occurred in Aarhus-Denmark (1786 mg per day in men and $1626 \mathrm{mg}$ per day in women) and the lowest in Greece (744 mg per day in men and $584 \mathrm{mg}$ per day in women). The most important food sources of total polyphenols were coffee, tea, and fruits. Among 437 different individuals, polyphenols in 94 were consumed at a level $1 \mathrm{mg}$ per day. The most abundant were caffeoylquinic acids and the proanthocyanidin oligomers and polymers.

Regarding DPPH antiradical activity, many authors have shown a high degree of correlation between the TPC and DPPH antiradical activity. For example, in a study on wines, the correlation was $r=0.970$. In a study with raspberries, the antiradical activity of the extracts was in good correlation with their total phenol (TPC) and ellagitannins concentration, with correlation coefficients $r=0.96$ and 0.92 , respectively (Viškelis et al., 2010). This is in agreement also with their previous study, which demonstrated very good correlation $(r=0.97)$ between the antiradical activity of berry fruits and their TPC (Viskelis et al., 2009). These findings explain similar tendencies and the close correlation between total phenol polyphenols and DPPH antiradical activity $(r=0.981)$ in our study as well.

The total antioxidant capacity $\mathrm{ABTS}^{+}$according to literature data show high correlation with TPC $(\mathrm{r}=0.929)$ (Paixćo et al., 2007) also. In our study the correlation coefficient between TPC and $\mathrm{ABTS}^{+}$was $\mathrm{r}=0.879$, although it was lower than the correlation with DPPH. It is possible that the antioxidant capacity of $\mathrm{ABTS}^{+}$is affected not only by polyphenols, but also by other antioxidants in products, such as ascorbic acid and tocopherols.

It is well known that minerals are of the same importance as vitamins and other bioactive compounds in our every day's diet. According to the British Nutrition Foundation, the body requires different amounts of each mineral because each mineral has a different set of functions. Requirements vary according to age, sex and physiological state (for example pregnancy). They may also be influenced by state of health. The bioavailability of a mineral may be influenced by a variety of factors. Bioavailability will depend upon the 
chemical form of the mineral, other substances present in the diet and the individual person's needs as determined by how much of the nutrient is already stored in the body. This is because the body has sensitive mechanisms for preventing storage of nutrients that can be damaging in excess. For example, the bioavailability of iron from plant sources (non-haem iron) is relatively poor compared with iron from meat (haem iron), but absorption is increased when vitamin $\mathrm{C}$ is consumed during the same meal because the vitamin $\mathrm{C}$ converts it to a more bioavailable chemical form. Our study with nine samples of special texture-modified food for dysphagia patients (Table 3 ) showed that it was not possible to ensure all necessary minerals using only mixtures of plant-based products, and it could be suggested to use some premixes with extra amounts of $\mathrm{Zn}, \mathrm{Fe}, \mathrm{Cu}, \mathrm{Mo}$, and Se.

According to the findings of Bonetti et al. (2017), B group vitamins and choline are certainly essential nutrients for adequate brain development, function, and protection. A balanced diet rich in fruits and vegetables and minimal intake of foods of animal origin, in the absence of malabsorption and severe comorbidities, should ensure a sufficient provision of the necessary micronutrients for the maintenance of normal neurological functions. Elderly individuals often require a higher intake of B group vitamins, probably because of an expected reduced absorption capability and the onset of concomitant age-related conditions (e.g., increased oxidative stress, burden of acquired organ damage, and impaired buffer mechanisms due to abnormal metabolic activity). Most $\mathrm{B}$ group vitamins (with vitamins $\mathrm{B}_{3}, \mathrm{~B}_{6}$, and perhaps $B_{9}$ as exceptions) are almost surely safe even at intake levels reached with food fortification or supplements. Despite the conclusions of Bonetti et al. (2017), our investigations showed low levels of vitamins $\mathrm{B}_{1}, \mathrm{~B}_{2}, \mathrm{~B}_{3}$, and $\mathrm{B}_{6}$ in all our plant-based pure-soup and dessert products for dysphagia patients. Therefore, some extra addition of these vitamins, as well as vitamin $\mathrm{D}_{3}$, which was lacking, are recommended for such plant-based products to ensure supplementation with all necessary vitamins.

\section{CONCLUSIONS}

The total carotene concentration in texture-modified puree-soups is higher than in desserts. Dessert D3 and puree-soup S7 had the highest carotene concentration. The total phenol concentration was higher in desserts than in puree-soups. The highest total phenol concentration was for sample D5, when calculated per $100 \mathrm{~g}$ of product, but in D3 when calculated per $100 \mathrm{kcal}$.

It is possible to ensure the necessary vitamin $\mathrm{B}_{9}$ and $\mathrm{E}$ vitamin concentration with all prepared puree-soup and dessert samples, but vitamins $\mathrm{A}$ and $\mathrm{B}_{1}, \mathrm{~B}_{2}, \mathrm{~B}_{3}, \mathrm{~B}_{6}$ did not reach the necessary amounts.

All prepared puree-soup and dessert samples are good sources of $\mathrm{Cr}, \mathrm{K}, \mathrm{Mn}$, and $\mathrm{Mg}$, but it is difficult to ensure the necessary $\mathrm{Zn}$ and $\mathrm{Fe}$ amounts with most of the samples.
The amount of $\mathrm{D}_{3}$ vitamin, minerals ( $\mathrm{J}, \mathrm{Mo}$ and $\mathrm{Se}$ ) were below the detection level for all samples.

For improvement of plant-based texture-modified products for dysphagia patients, the addition of minerals like $\mathrm{Zn}, \mathrm{Fe}$, $\mathrm{Cu}, \mathrm{Mo}$, and Se and vitamins $\mathrm{B}_{1}, \mathrm{~B}_{2}, \mathrm{~B}_{3}, \mathrm{~B}_{6}$, and $\mathrm{D}_{3}$ is recommended.

\section{ACKNOWLEDGMENTS}

This research was supported by European Innovation Partnership for Agricultural Productivity and Sustainability Working Group Cooperation Project No 18-00-A01612000006 "Development of medicinal food for patients of malnutrition/dysphagia, creating new, nationally significant product with a high added value" (2018 to 2021).

\section{REFERENCES}

Beck, A. M., Kjaersgaard, A., Hansen, T., Poulsen, I. (2018). Systematic review and evidence based recommendations on texture modified foods and thickened liquids for adults (above 17 years) with oropharyngeal dysphagia: An updated clinical guideline. Clin. Nutr., 37 (6), 1980-1991.

Bonetti, F., Brombo, G., Zuliani, G. (2017). Chapter 15. The Role of B Group Vitamins and Choline in Cognition and Brain Aging. In: Ross, R. Nutrition and Functional Foods for Healthy Aging. Academic Press, pp. 139-158.

Cichero, J. A. Y., Lam, P., Steele, C. M., Hanson, B., Chen, J., Dantas, R. O., Duivestein, J., Kayashita, J., Lecko, C., Murray, J., Pillay, M., Riquelme, L., Stanschus, S. (2017). Development of international terminology and definitions for texture-modified foods and thickened fluids used in dysphagia management: The IDDSI framework. Dysphagia, 32 (2), 293-314.

Costa, A., Carrión, S., Puig-Pey, M., Juárez, F., Clavé, P. (2019). Triple adaptation of the mediterranean diet: Design of a meal plan for older people with oropharyngeal dysphagia based on home cooking. Nutrients, 11 (2), 425 .

Del Rio, D., Rodriguez-Mateos, A., Spencer, J. P. E., Tognolini, M., Borges, G., Crozier, A. (2013). Dietary (poly)phenolics in human health: Structures, bioavailability, and evidence of protective effects against chronic diseases. Antioxidants Redox Signal., 18 (14), 1818-1892.

Drózdz, P., Sežiene, V., Wójcik, J., Pyrzyńska, K. (2018). Evaluation of bioactive compounds, minerals and antioxidant activity of lingonberry (Vaccinium vitis-idaea L.) Fruits. Molecules, 23 (1), 53.

Ermakov, A. I. (ed.) (1987). Methods of biochemical research of plants. [Ермаков, А. И. (ред.). Методы биохимического исследования растений]. Agropromizdat, Leningrad. 430 pp. (in Russian).

Floegel, A., Kim, D. O., Chung, S. J., Koo, S. I., Chun, O. K. (2011). Comparison of ABTS/DPPH assays to measure antioxidant capacity in popular antioxidant-rich US foods. J. Food Compos. Anal., 24 (7), 1043-1048.

Khan, N. C., West, C. E., De Pee, S., Bosch, D., Ha, D. P., Hulshof, P. J. M., Ha, H. K., Verhoef, H., Hautvast, J. G. A. J. (2007). The contribution of plant foods to the vitamin A supply of lactating women in Vietnam: A randomized controlled trial. Amer. J. Clin. Nutr., 85 (4), 1112-1120.

Klava, D., Kampuse, S., Kruma, Z., Ozola, L., Galoburda, R., Straumite, E. (2019). The evaluation of organically grown apple cultivars for special diet puree production. In: Proceedings of FoodBalt 2019 13th Baltic Conference of Food Science and Technology. "Food. Nutrition. Well-Being." Latvia University of Life Sciences and Technologies, Jelgava, pp. $143-148$.

Martínez-Valverde, I., Periago, M. J., Ros, G. (2000). Nutritional importance of phenolic compounds in the diet. Arch. Latinoam. Nutr., 50 (1), 5-18. 
Moret-Tatay, A., Rodríguez-García, J., Martí-Bonmatí, E., Hernando, I., Hernández, M. J. (2015). Commercial thickeners used by patients with dysphagia: Rheological and structural behaviour in different food matrices. Food Hydrocoll., 51, 318-326.

National Dysphagia Diet Task Force, American Dietetic Association (2002). National dysphagia diet: Standardization for optimal care. American Dietetic Association. 47 pp.

National Patient Safety Agency. (2011). Dysphagia Diet Food Texture Descriptors.

http://www.hospitalcaterers.org/media/1160/dysphagia-descriptors.pdf (accessed 03.01.2022).

Okkels, S. L., Saxosen, M., Bügel, S., Olsen, A., Klausen, T. W., Beck, A. M. (2018). Acceptance of texture-modified in-between-meals among old adults with dysphagia. Clin. Nutr. ESPEN, 25, 126-132.

Olas, B. (2018). Berry phenolic antioxidants - implications for human health? Front. Pharmacol., 9, 1-14.

Ozola, L., Kampuse, S. (2018). Influence of heat treatment methods on bioactive compound concentrations in pumpkin - Guelder rose (Viburnum opulus) sauces. Proc. Latv. Acad. Sci., Section B, 72 (2), 97-102.

Paixćo, N., Perestrelo, R., Marques, J. C., Cāmara, J. S. (2007). Relationship between antioxidant capacity and total phenolic content of red, rosé and white wines. Food Chem., 105 (1), 204-214.

Poludek-Fabini, R., Beirix, T. (1981). Organic analyses. [Полюдек-Фабини, P., Бейрих, Т. Органический анализ]. Khimia, Leningrad, pp. 499-500 (in Russian).

Singleton, V. L., Orthofer, R., Lamuela-Raventós, R. M. B. T. (1999). Analysis of total phenols and other oxidation substrates and antioxidants by means of Folin-ciocalteu reagent. In: Oxidants and Antioxidants. Part A. Academic Press.Vol. 299, pp. 152-178.

Received 22 March 2021

Accepted in the final form 9 January 2022
Sungsinchai, S., Niamnuy, C., Wattanapan, P., Charoenchaitrakool, M., Devahastin, S. (2019). Texture modification technologies and their opportunities for the production of dysphagia foods: A review. Compr. Rev. Food Sci. Food Saf., 18 (6), 1898-1912.

Tang, G. (2010). Bioconversion of dietary provitamin A carotenoids to vitamin A in humans. Amer. J. Clin. Nutr., 91 (5), 1468-1473.

Tang, G., Qin, J., Dolnikowski, G. G., Russell, R. M., Grusak, M. A. (2005) Spinach or carrots can supply significant amounts of vitamin A as assessed by feeding with intrinsically deuterated vegetables. Amer. J. Clin. Nutr., 82 (4), 821-828.

Viskelis, P., Rubinskiene, M., Jasutiene, I., Šarkinas, A., Daubaras, R., Česoniene, L. (2009). Anthocyanins, antioxidative, and antimicrobial properties of american cranberry (Vaccinium macrocarpon Ait.) and their press cakes. J. Food Sci., 74 (2), C157-61.

Viskelis, P., Rubinskienė, M., Bobinaitė, R., Dambrauskienė, E. (2010). Bioactive compounds and antioxidant activity of small fruits in Lithuania. J. Food, Agr. Env., 8 (3-4), 259-263.

Yu, L., Perret, J., Harris, M., Wilson, J., Haley, S. (2003). Antioxidant properties of bran extracts from "Akron" wheat grown at different locations. $J$. Agric. Food Chem., 51 (6), 1566-1570.

Zamora-Ros, R., Rothwell, J. A., Scalbert, A., Knaze, V., Romieu, I., Slimani, N., Fagherazzi, G., Perquier, F., Touillaud, M., Molina-Montes, E., et al. (2013). Dietary intakes and food sources of phenolic acids in the European Prospective Investigation into Cancer and Nutrition (EPIC) study. Brit. J. Nutr., 110 (8), 1500-1511.

Zargaraan, A., Rastmanesh, R., Fadavi, G., Zayeri, F., Mohammadifar, M. A. (2013). Rheological aspects of dysphagia-oriented food products: A mini review. Food Sci. Hum. Wellness, 2 (3-4), 173-178.

\section{UZTURVIELU SASTĀVA ANALİZE AUGU BĀZES DISFĀGIJAS PACIENTIEM PIELĀGOTĀS STRUKTŪRAS PRODUKTOS}

Pasaulē ir aptuveni 590 miljoni cilvēku ar rīšanas traucējumiem (disfāgiju), un viņiem ir nepieciešami pārtikas produkti ar modificētu struktūru, lai nodrošinātu uztura uzṇemšanu ikdienā. Šì pētījuma mērkis bija radīit jaunus produktus ar modificētu struktūru un novērtēt to bioaktīvo savienojumu un minerālvielu saturu. Tika izstrādāti deviṇi jauni produkti (pieci deserti un četras biezzupas) no augu valsts sastāvdaḷām, pievienojot olbaltumvielu avotus, rapšu ellıu, askorbīnskābi un citas sastāvdaḷas. Paraugus vārīja vakuumā, piecas minūtes sterilizēja $115^{\circ} \mathrm{C}$ temperatūrā un pārbaudīja to bioaktīvo savienojumu saturu (kopējo karotīnu daudzumu, kopējo fenolu saturu, ABTS ${ }^{+}$, DPPH radikāḷ saistī̌̌anas spēju), septiņu vitamīnu un trīspadsmit minerālvielu saturu, kas ir nozīmīgi cilvēka uzturā. Iegūtie dati parādīja, ka bioaktīvo savienojumu saturs katrā paraugā bija atškirīgs, — tas bija sagaidāms katra produkta dažādo sastāvdaḷu saraksta dēḷ. Minerālu savienojumu satura analīze parādīja zemu joda, molibdēna, selēna līmeni. Produktos vispār netika konstatēts $\mathrm{D}_{3}$ vitamīns un bija zems B grupas vitamīnu līmenis. Kopumā analizētais produktu sastāvs norādīja, ka šo produktu dabiskais fons nav pietiekams, lai nodrošinātu cilvēka organismu ar visiem nepieciešamajiem vitamīniem un minerālvielām, un labākais risinājums varētu būt šo produktu papildināšana ar vitamīnu un minerālvielu kompleksiem. 